\title{
Feasibility of Screw Placement in the Occipital Condyle of Chinese Patients for Occipitocervical Arthrodesis: A Cadaveric Study
}

\section{Oksipitoservikal Artrodez için Çinli Hastalarm Oksipital Kondiline Vida Yerleştirme Uygunluğu: Bir Kadavra Çalışması}

Zuochong $\mathrm{YU}^{1}$, Xiaosheng $\mathrm{MA}^{2}$, Jianyuan JIANG ${ }^{2}$, Xiang JIN², Feizhou $\mathrm{LV}^{2}$, Lixun WANG ${ }^{2}$, Xinlei XIA², Hongli WANG ${ }^{2}$

${ }_{1}^{1}$ Fudan University, Jinshan Hospital, Department of Orthopaedic Surgery, Shanghai, China

${ }^{2}$ Fudan University, Huashan Hospital, Department of Orthopaedic Surgery, Shanghai, China

Zuochong $Y U$ and Xiaosheng $M A$ contributed equally to this work.

Corresponding Author: Jianyuan JIANG / E-mail: tjyd327@126.com

\section{ABSTRACT}

AIM: The feasibility of computed tomography (CT) and two-dimensional (2D) reconstruction-guided screw placement in the occipital condyle (OC) of Chinese patients was investigated.

MATERIAL and METHODS: Twenty (40 OCs) fresh cadaveric specimens with intact superior cervical spine and occipital bones were placed in the prone position. Simulated screw placement was achieved by placing $4.0 \mathrm{~mm}$ diameter virtual screws with the help of the 2D reconstruction CT scan image technology. Maximal screw length, angulation in the sagittal and transverse planes, and medial and cranial base OC entry points were determined and recorded. Actual screw placement was achieved by similar placement; actual position and angulation were determined by postoperative CT scanning.

RESULTS: Screws were successfully inserted in 36 of 40 (90\%) OCs. Four ruptures of the medial OC wall were on the left side. Actual screw placement did not damage the hypoglossal canal, and no screws pierced the medial or lateral OC walls. Females displayed significantly smaller left and right maximum screw lengths than males $(p<0.05)$; no other significant gender differences were noted.

CONCLUSION: The results can feasibly accommodate 4-mm OC screws for OA treatment. As in other populations, OC shape and size is smaller in females and varies in Chinese individuals, necessitating individualized imaging for good outcomes.

KEYWORDS: Occipital condyle, Occipitocervical arthrodesis, Screw fixation, Simulation, Computed tomography, Occipitocervical fixation

ÖZ

AMAÇ: Çinli hastaların oksipital kondiline (OK) bilgisayarlı tomografi (BT) ve iki boyutlu (2B) rekonstrüksiyon rehberliğinde vida yerleştirmenin uygunluğu incelendi.

YÖNTEM ve GEREÇLER: Intakt üst servikal omurga ve oksipital kemiklere sahipyirmi (40 OK) taze kadavra örneği yüzüstü pozisyonda yerleştirildi. $2 B$ rekonstrüksiyon $B T$ tarama görüntü teknolojisinin yardımılla 4,0 mm çaplı sanal vidalar yerleştirilerek vida yerleştirme simülasyonu yapıldı. Maksimum vida uzunluğu, sagittal ve transvers düzlemlerde angülasyon ve medial ve kraniyal kaide OK giriş noktaları belirlendi ve kaydedildi. Fiili vida yerleştirme benzer yerleştirme ile elde edildi; fiili pozisyon ve angülasyon postoperatif BT taramayla belirlendi.

BULGULAR: Vidalar 40 OK'nin 36'sında (\%90) başarıyla yerleştirildi. Medial OK duvarındaki dört rüptür sol taraftaydı. Fiili vida yerleştirme hipoglossal kanala zarar vermedi ve hiçbir vida medial veya lateral OK duvarlarını delmedi. Kadınlarda sol ve sağ maksimum vida uzunlukları erkeklere göre önemli ölçüde daha küçüktü $(p<0,05)$; başka bir önemli cinsiyet farkı gözlenmedi.

SONUÇ: Sonuçlar OA tedavisinde $4 \mathrm{~mm}$ OK vidaların kullanılabileceğini düşündürmektedir. Diğer popülasyonlarda olduğu gibi OK şekli ve büyüklüğü kadınlarda daha küçüktür ve Çinli bireyler arasında farklılık gösterip iyi bir sonuç alınması için bireyselleştirilmiş görüntüleme gerektirir.

ANAHTAR SÖZCÜKLER: Oksipital kondil, Oksipitoservikal artrodez, Vida fiksasyonu, Simülasyon, Bilgisayarlı tomografi, Oksipitoservikal fiksasyon 


\section{INTRODUCTION}

Occipitocervical joint stability in patients with degenerative diseases, trauma, or tumor due to decompressive surgery can be improved by occipitocervical arthrodesis. Screw and rod fixation techniques for achieving occipitocervical joint stability in such patient populations have been successful (20). This important surgical method has evolved rapidly over the past decade (20). These techniques are shown to be useful in alleviating potentially life-threatening symptoms, such as respiratory dysfunction caused by pathological instability and compression of the medulla oblongata and spinal cord (20). Variations in extracranial measurements between male and female sex have been well-documented (11). However, there exists a lacuna that majority of these studies have been conducted in patients of Western countries; potential anatomical variations in Chinese patients affecting the feasibility of these techniques remain undocumented.

The occipitocervical region consists of the occipital bone, atlas, and axis, with anatomical significance as the 'hinge' of the head and spine. Placement of screws as opposed to plate systems in the occipitocervical region is a relatively recent advancement over conventional arthrodesis of the cervical spine and external occipital protuberance (4). Recent improvements in screw placement in the atlantooccipital joint and occipital condyle (OC) have made it a reliable alternative to traditional occipital plate fixation (17), producing adverse events (AEs) in less than $12 \%$ of patients (11).

Current internal fixation methods for clinical occipitocervical arthrodesis are broadly divided into strategies that employ internal fixation with wire binding and those that involve screw plate or rod fixation (20). However, wire fixation has disadvantages such as poor biomechanical performance, damage to bones, dural tear, cerebrospinal fluid leakage, and even nervous injury in adjacent spinal cord regions (20). Whereas, screw fixation is more invasive technique reported to achieve good biomechanical stability, fatigue resistance, and preservation of neural canals (20).

However, there exists a risk of epidural hematoma and potential damage to brain tissues due to variance in the thickness of occipital regions, which may be as thin as $2 \mathrm{~mm}$ in some areas. In such cases the screws sometimes provide insufficient mechanical strength for fixation and can result in occipital screw breakaway (21). In cadaveric studies, comprehensive understanding of the anatomy of $O C$ and subsequently selecting proper screw insertion angles and positions could avoid unfavorable outcomes of screw placement such as hypoglossal injury (6).

In different patients, the OC can exhibit oval, dual semicircle, prismatic, flat, pea-shaped, and convex shapes $(1,3,12)$, through ovular shapes are most common and less frequent variations, such as kidney-like, S-like, eight-like, triangle, and ring-like, shapes have also been reported (13). Due to relatively long shaft diameters, OCs with oval shapes are the most suitable for screw placement (13). Furthermore, recent reports have indicated that a $12-\mathrm{mm}$ security area exists within most OCs $(2,10)$. Within this region, drilling does not damage the hypoglossal canal and the enclosed hypoglossal nerve, generally located less than $12 \mathrm{~mm}$ from the posterior margin of the OC (12). By using advanced imaging methods, such as computed tomography (CT) scanning and reconstruction techniques (20), screws can be safely placed into the $O C$ in many patients.

The objective of the current study was to explore the feasibility of screw placement in the OC for Chinese occipitocervical arthrodesis patients and to obtain the preliminary results.

\section{MATERIAL and METHODS}

\section{Cadaveric Specimens}

The cadavers were donated. Twenty fresh cadaveric heads with visibly intact upper cervical regions were subjected to occipitocervical arthrodesis by screw fixation. Initially, all specimens were subjected to preliminary $C T$ scanning with a $1.25-\mathrm{mm}$ section thickness to confirm the intactness of superior cervical spine and occipital bones. Clinical and demographic characteristics, including age, gender, and cause of death, were recorded for all specimens. The study was approved by the Medical Ethics Committee of the hospital.

\section{Determination of Surgical Parameters by CT Scanning}

In order to examine the $\mathrm{OC}$, transverse and sagittal CT scans were conducted in all specimens using a $1.25-\mathrm{mm}$ section thickness on both the left and right sides. Any specimens with destruction or deformity in atlantooccipital joint were excluded; only specimens with intact occipital bones and atlas were included in the study. For right and left OCs of each specimen, the following surgical parameters were measured and recorded: maximal sagittal length, angle between virtual screw and sagittal plane (angulation in the sagittal plane), angle between virtual screw and the horizontal plane (angulation relative to the transverse plane), distance from entry point to base of the head (entry to the OC cranial base), and distance from entry point to medial edge of the OC (entry to the OC medial edge) (Figure 1, 2).

\section{Simulated Screw Placement}

CT scans were used to build two-dimensional (2D) reconstructions of the $O C$ and surrounding areas for each specimen by an experienced radiologist; the screw placement was simulated using a virtual screw with a diameter of $4.0 \mathrm{~mm}$ (4-mm screw) placed at the maximal sagittal length, carefully avoiding interruption of the hypoglossal canal.

Using the software provided by the manufacturer (advance workstation 4.3 GE Healthcare, Shanghai, China), images were reconstructed and adjusted from multiple angles on the CT machine to optimize the position of virtual screw. Entry position and angle were recorded for later use in actual screw placement.

\section{Actual Screw Placement}

Each specimen was placed in a prone position (face down), 
with a holder mainly fixed on the parietal region and bilateral temporal regions. An experienced surgeon performed the actual screw placement through the predetermined entry position and angle in accordance with each simulated screw

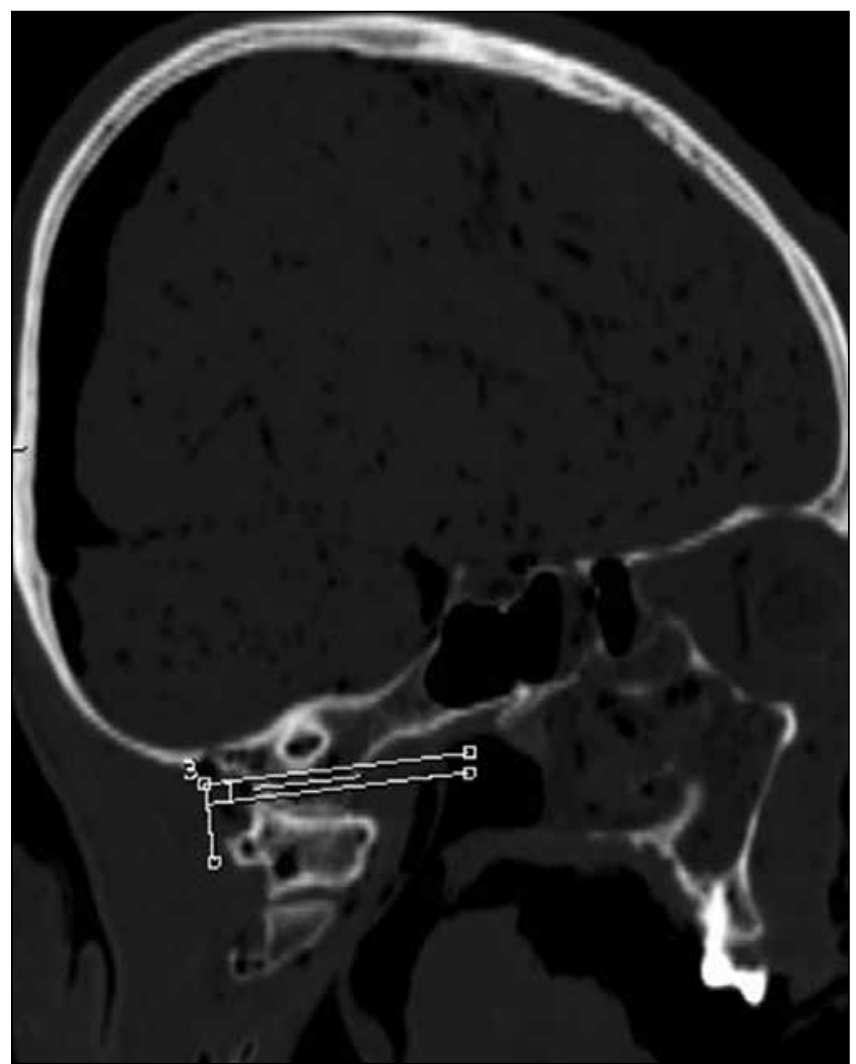

Figure 1: Sagittal CT scan demonstrating simulated screw placement.

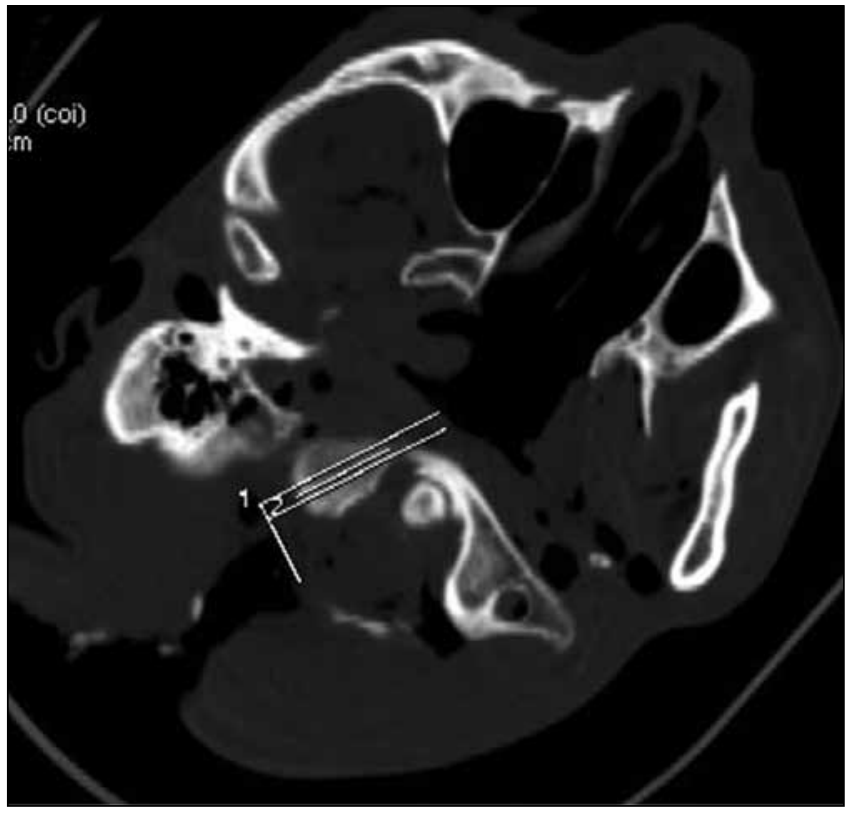

Figure 2: Transverse CT scan demonstrating simulated screw placement. placement procedure. Entry point and angle of screws were determined using vernier calipers and protractors in accordance with measurement data; actual screws were placed manually in all specimens. Briefly, a posterior midline excision was created to expose the atlantoaxial joint to the external occipital protuberance, clearly revealing the posterior arch of the atlas and vertebral artery on the superior margin of the arch. The posterior arch of atlas was resected to avoid oppression of the vertebral artery by screw placement and thus increase the likelihood of success. The edge of the superior articular fovea of the atlas was removed to reveal the lower margin of the $\mathrm{OC}$ as the occipital condyle is located in the superior articular fovea of the atlas. Bilateral skin and muscle were penetrated with a surgical electric drill and the screws were placed. A single hole was drilled to place a 4.0$\mathrm{mm}$ screw.

\section{Postoperative Outcome Assessments}

A posterior incision was made on the skin of occipital-cervical area, and the deep fascia was separated to exposure the occipital bone and atlantoaxial joint. After screw placement in each specimen, the medial and lateral walls of the OC were exposed by stripping the surrounding tissues carefully with a surgical scalpel to determine rupture occurrence in the $\mathrm{OC}$ under direct vision. Additionally, all specimens were subjected to CT scanning (GE Healthcare, Shanghai, China) with 1.25$\mathrm{mm}$ section thickness to confirm medial and lateral $O C$ walls damage and identify damage to the hypoglossal canals.

\section{Statistical Analysis}

All data were recorded as means \pm standard deviation (SD) and were analyzed with SPSS v. 18.0 (SPSS, Inc., IBM, USA). Data on sides and genders were compared by paired $t$-tests. $P$-values of less than 0.05 were considered as statistical significance $(p<0.05)$.

\section{RESULTS}

\section{Clinical and Demographic Characteristics of Cadaveric Specimens}

All 20 specimens (40 OCs) (M:F, 8:12; mean ages 65.4 \pm 3.2 and $67.2 \pm 1.9$, respectively) exhibited fully intact structures above the second cervical vertebra (C2) of the spine without visual or $\mathrm{CT}$ deformity prior to the experiments. All specimens were of Chinese patients. The number of male and female specimens was similar; no statistically significant differences $(p>0.05)$ were reported in the number of male and female specimens. The causes of death for were advanced tumor $(6 / 20,20 \%)$, cardiovascular disease $(5 / 20,25.0 \%)$, trauma $(4 / 20,20.0 \%)$, multiple organ failure $(3 / 20,15.0 \%)$, and cerebral hemorrhage $(2 / 20,10.0 \%)$ (Table I). Complete data of individuals are shown in Supplementary Table I.

\section{Surgical Parameters by Gender}

Overall, the simulated sagittal plane angulation was $22.9 \pm 3.1$ degrees (left) and $21.2 \pm 1.4$ degrees (right); the simulated transverse angulation was $8.2 \pm 0.5$ degrees (left) and $4.0 \pm 1.6$ 
degrees (right). In male patients, the maximal length was significantly greater than that observed in female patients on both the left and right sides ( $22.6 \pm 0.9$ vs. $20.8 \pm 1.4,22.7 \pm 1.1$ vs. $20.0 \pm 1.3$, respectively; $p=0.0054, p=0.0002$ ). Similarly, males exhibited numerically higher angulation in the sagittal plane on both sides than females $(23.3 \pm 3.2$ vs. $22.7 \pm 3.4,21.4 \pm 1.3$ vs. $21.0 \pm 1.5$, respectively; $p=0.7032, p=0.5781$ ), though this difference was statistically non-significant. No statistically significant differences were observed between angulation relative to the transverse plane, entry to the OC medial edge, or entry to the cranial base between male and female patients $(p>0.05)$. The parameters used for virtual and actual screw placement are summarized in Table II.

\section{Surgical Outcomes}

Resection of the posterior arch of the atlas reduced oppression of the vertebral artery caused by screw placement. Resection of the posterior arch was employed to avoid the damage of vertebral artery, thereby increasing the likelihood of successful screw placement as oppression to the vertebral artery can cause failure of OC screw placement. In contrast, preservation of the posterior arch of the atlas resulted in difficulty in exposing the $\mathrm{OC}$ and placing screws. Furthermore, oppression of the vertebral artery was reported in all cases (Figure 3). After fixation, rupture of the medial wall of the left

Table I:. Basic Characteristics of Cadaveric Specimens

\begin{tabular}{|l|l|r|}
\hline Characteristic & & Value \\
\hline \multirow{3}{*}{ Gender } & Male & $8(40.0 \%)$ \\
& Female $(y r)$ & $12(60.0 \%)$ \\
& Male & $65.4 \pm 3.2$ \\
& Female & $67.2 \pm 1.9$ \\
\hline \multirow{3}{*}{ Cause of death } & Trauma & $4(20.0)$ \\
& Multiple Organ Failure & $3(15.0)$ \\
& Cerebral Hemorrhage & $2(10.0)$ \\
& Cardiovascular Disease & $5(25.0)$ \\
& Advanced Tumor & $6(30.0)$
\end{tabular}

OC was observed visually and confirmed by CT scanning in cadaveric specimen $1,3,5$, and 18; however, the medial and lateral walls of the OC remained intact in these specimens. In all other OCs $(36 / 40,90 \%)$ screw fixation resulted in no apparent destruction of the medial and lateral walls of the OC by either visual or CT scan examination. Furthermore, no specimens exhibited damage to the hypoglossal canal or hypoglossal nerve structures (Figure 4A-D).

\section{DISCUSSION}

For till now, the current study is possibly the first of its kind demonstrating the feasibility of screw placement in the OC for occipitocervical arthrodesis in Chinese population. The current study demonstrated that $\mathrm{CT}$ scanning and $2 \mathrm{D}$ reconstruction can be effectively used to determine optimal position and angulation for screw placement in the OC of Chinese patients, thereby successfully achieving occipitocervical arthrodesis. Of the 20 cadaveric specimens examined, only four exhibited rupture in the medial walls of the OC following surgery, and none exhibited hypoglossal canal or nerve injury. Though further clinical study will be required to fully assess the safety of CT- and 2D reconstruction-guided OC screw placement for occipitocervical arthrodesis, it is assumed that technological

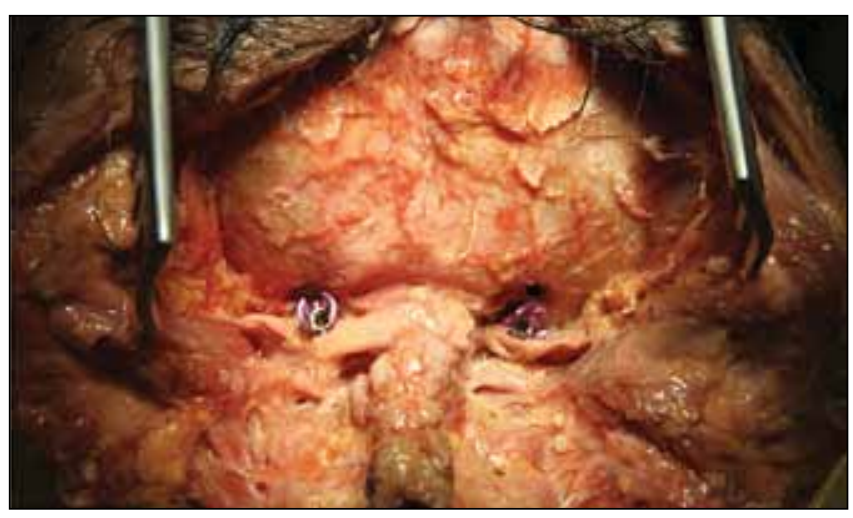

Figure 3: Actual placement of screws in the posterior midline. The occipital protuberance and posterior structure of $11-3$ are exposed. The right but not left posterior arch of atlas is excised.

Table II: Summary of Parameters Used for Virtual and Actual Screw Placement

\begin{tabular}{|c|c|c|c|c|c|c|}
\hline \multicolumn{2}{|c|}{ Gender/Side } & \multirow{2}{*}{$\begin{array}{l}\text { Maximal screw } \\
\text { length }(\mathrm{mm}) \\
22.6 \pm 0.9\end{array}$} & \multirow{2}{*}{$\begin{array}{l}\text { Angulation in the } \\
\text { sagittal plane }\left({ }^{\circ}\right) \\
23.3 \pm 3.2\end{array}$} & \multirow{2}{*}{$\begin{array}{c}\text { Angulation relative } \\
\text { to transverse } \\
\text { plane }\left({ }^{\circ}\right) \\
8.0 \pm 1.8\end{array}$} & \multirow{2}{*}{$\begin{array}{c}\begin{array}{c}\text { Entry to } O C \text { medial } \\
\text { edge }(\mathrm{mm})\end{array} \\
8.0 \pm 1.1\end{array}$} & \multirow{2}{*}{$\begin{array}{c}\text { Entry to cranial } \\
\text { base (mm) } \\
10.5 \pm 1.9\end{array}$} \\
\hline M & $\mathrm{L}$ & & & & & \\
\hline $\mathrm{F}$ & $\mathrm{L}$ & $20.8 \pm 1.4$ & $22.7 \pm 3.4$ & $8.3 \pm 2.8$ & $7.5 \pm 0.6$ & $10.0 \pm 1.5$ \\
\hline \multicolumn{2}{|c|}{$t$-value } & 3.16 & 0.39 & 0.29 & 1.27 & 0.64 \\
\hline \multicolumn{2}{|c|}{$P$-value } & 0.0054 & 0.7032 & 0.7717 & 0.2194 & 0.5312 \\
\hline M & $\mathrm{R}$ & $22.7 \pm 1.1$ & $21.4 \pm 1.3$ & $8.6 \pm 2.0$ & $7.6 \pm 0.5$ & $9.9 \pm 1.1$ \\
\hline $\mathrm{F}$ & $\mathrm{R}$ & $20.0 \pm 1.3$ & $21.0 \pm 1.5$ & $7.6 \pm 1.2$ & $7.2 \pm 0.7$ & $9.9 \pm 1$ \\
\hline \multicolumn{2}{|c|}{$t$-value } & 4.77 & 0.57 & 1.45 & 1.36 & 0.14 \\
\hline \multicolumn{2}{|c|}{$P$-value } & 0.0002 & 0.5781 & 0.1652 & 0.1917 & 0.8868 \\
\hline
\end{tabular}

Abbreviations: male $(M)$, female (F), left $(L)$, right $(R)$. 
improvements may improve the feasibility and safety of this procedure as an alternative to conventional plate or wire fixation in Chinese patients.

In a recent review, occipitocervical arthrodesis associated with screw or rod fixation produced superior results in a wide crosssection of patients undergoing occipitocervical arthrodesis for inflammatory diseases (20). However, screw and rod fixation methods were less beneficial to tumor patients. Furthermore, a number of studies have recently suggested that OC screw fixation can be a viable and safe alternative for patients who are not eligible for occipital steel plate fixation $(6,7,15-18)$. Recent advent and improvements in surgical imaging and reconstruction have made occipitocervical arthrodesis by screw fixation a valuable tool in the surgical armamentarium of medical practitioners around the world. The current study, however, provides the first preliminary confirmation that these recommendations may be widely applicable in Chinese patients.

The margin for error during this screw fixation is relatively small and extremely specific to individual anatomy (1, 3,
$12,13)$. It was reported that, to achieve the insertion of screw parallel to the base of the skull, the optimal angle for screw placement should be at the medial angulation of $\geq 20$ degrees relative to the sagittal midline (8). The same report also observed that the variations in the insertion angle of 10 degrees in the cranial or caudal directions could increase the risk of damage to the hypoglossal canal and nerve (8). These findings are consistent with the results of the current study.

In an anthropological context, differences in male and female OC anatomy in American and European individuals are well established; females generally having a shorter and smaller OC than males, a parameter often considered in forensic examinations $(5,19)$. The gender dimorphism in Chinese individuals is, however, rarely reported, appearing only briefly in a recent analysis of variation between male and female skull anatomical characteristics in predominantly Thai individuals (14). Notably, this report, consistent with the current findings, indicated that in Thai and possibly Chinese individuals females generally have smaller and narrower occipital condyles and mastoid processes, consistent with findings in Western
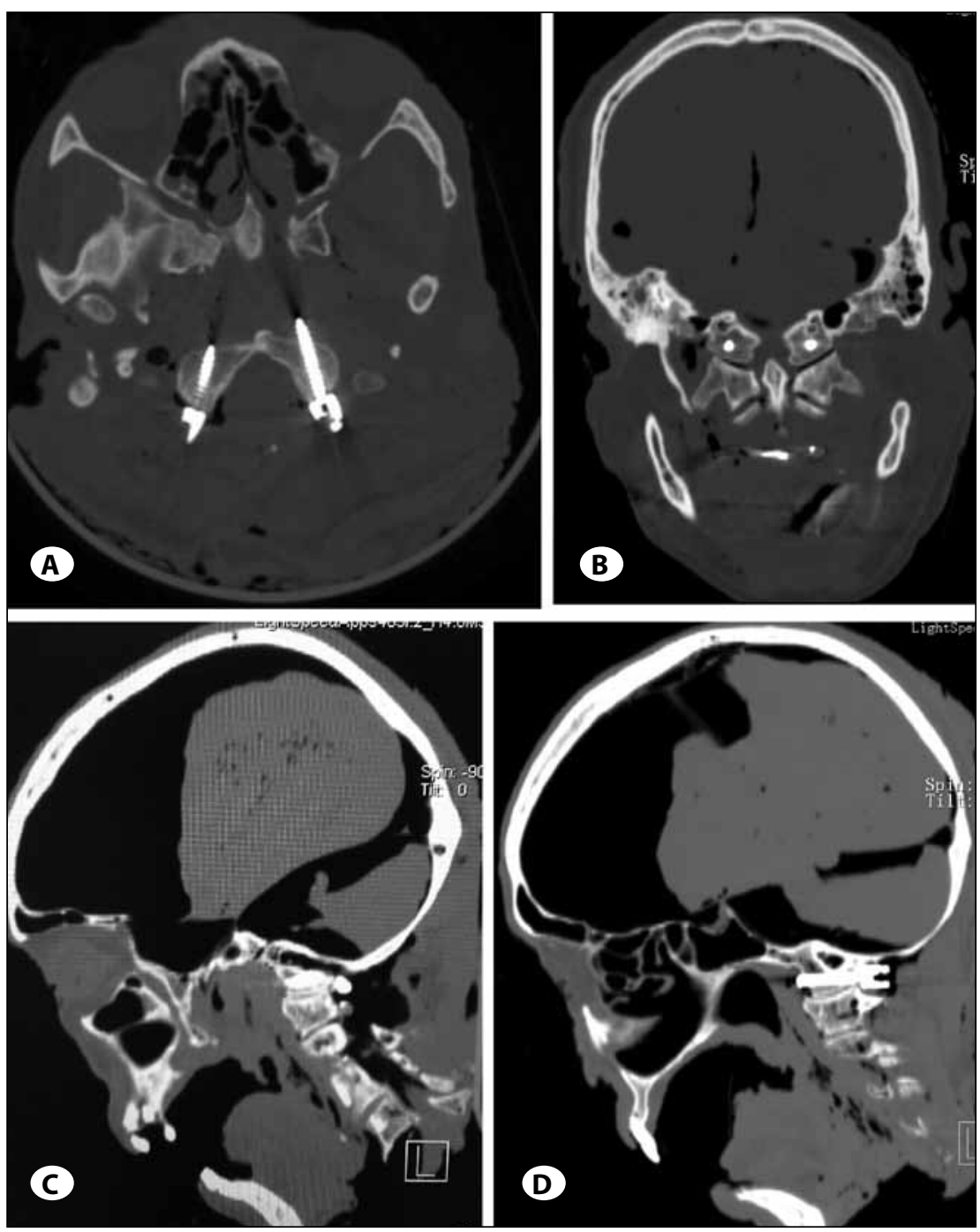

Figure 4A-D: Two-dimensional anatomic reconstructions of $\mathrm{OC}$ screw placement based on CT scan. A) indicates screw placement without damage to medial and lateral walls of OC. C-D) indicate that no injury to the hypoglossal canal was caused by screw placement. Arrows indicate the hypoglossal canal. 
individuals (14). The current study also reported that females required significantly shorter maximum screw lengths likely due to their generally smaller OCs, which may explain the greater prevalence of $O C$ wall rupture in females due to the smaller size and resultant smaller tolerances within the OC.

Generally, very little variation between left and right occipital condyles occurs within an individual (9), making it somewhat surprising that $\mathrm{OC}$ wall rupture was predominant on the left side in the current study. Due to the sensitivity of the procedure, this may be due in part to use of a preferential hand by the operator. Alternatively, naturally occurring anatomical or pathological alteration, such as that produced by osteoporosis or malignancy, in a single condyle may increase asymmetry and contribute to greater rupture occurrence on only a single side (9). Though such cases are relatively rare, this further emphasizes that usefulness of individualized imaging for both condyles prior to operation. The current findings, however, represent only a small portion of patients in the Chinese population, and further study of larger patient groups will be required to confirm these findings as well as the safety and efficacy of screw fixation in the OC.

Overall, these preliminary findings using cadaveric subjects indicate that occipitocervical arthrodesis by $4.0-\mathrm{mm}$ screw fixation of the $\mathrm{OC}$ is feasible in Chinese populations, as reported for other global populations, when supported by $C T$ imaging and $2 \mathrm{D}$ reconstruction prior to surgery. Furthermore, these results demonstrate that removal of a portion of the posterior arch of the atlas may be necessary to allow space for the vertebral artery and avoid iatrogenic oppression, though these results require confirmation in clinical patients before best-practice recommendations for surgery can be generated and widely implemented. Thus, the current study suggests that eligible Chinese patients may benefit from occipitocervical arthrodesis by screw fixation of the OC with careful consideration for individual patient anatomy as an alternative to conventional plate arthrodesis. However, this study has several disadvantages. It can be argued that the sample size of 20 cadavers is not adequate to draw firm conclusions when compared to previous studies. In this context, the practitioners should be aware of the high risk of injuries of nerves, arteries or even brain tissues during the process. Furthermore, bone mineral density and biomechanical tests were not conducted in this research. Also, we have not determined the strength of the screw used in the technique. We also have not studied a different approach in the context of the disruption.

\section{ACKNOWLEDGEMENTS}

The study was funded by the 2009 and 2010 National Natural Scientific Foundation of China (No. 30973029; No. 81071438), the 2010 Key Breakthroughs Programs of Shanghai Science and Technology Commission (No. 10441902200), and the 2010 Annual Health Public Welfare Industry Special Funds for Scientific Research Projects (No. 201002018) and the General Programs of Health Bureau of Jianshan District, Shanghai, China (JSKJ-KTMS-2013-09).

\section{REFERENCES}

1. Acikbas SC, Tuncer R, Demirez I, Rahat O, Kazan S, Sindel M, Saveren $M$ : The effect of condylectomy on extreme lateral transcondylar approach to the anterior foramen magnum. Acta Neurochir (Wien) 139:546-550, 1997

2. Barut N, Kale A, Turan Suslu H, Ozturk A, Bozbuga M, Sahinoglu $\mathrm{K}$ : Evaluation of the bony landmarks in transcondylar approach. Br J Neurosurg 23:276-281, 2009

3. Bozbuga M, Ozturk A, Bayraktar B, Ari Z, Sahinoglu K, Polat G, Gurel I: Surgical anatomy and morphometric analysis of the occipital condyles and foramen magnum. Okajimas Folia Anat Jpn 75:329-334, 1999

4. DC PTPGX: Applied anatomy of internal fixation of occipitalcervical fusion. Chinese Journal of Clinical Anatomy 16:132134,2000

5. Giles $\mathrm{E}$, Elliot $\mathrm{O}$ : Sex determination by discriminant function analysis of crania. Am J Phys Anthropol 21:53-68, 1963

6. La Marca F, Zubay G, Morrison T, Karahalios D: Cadaveric study for placement of occipital condyle screws: Technique and effects on surrounding anatomic structures. J Neurosurg Spine 9:347-353, 2008

7. Le TV, Dakwar E, Hann S, Effio E, Baaj AA, Martinez C, Vale FL: Computed tomography-based morphometric analysis of the human occipital condyle for occipital condyle-cervical fusion. J Neurosurg Spine 15:328-331, 2011

8. Le TV, Vivas AC, Baaj AA, Vale FL, Uribe JS: Optimal trajectory for the occipital condyle screw. J Spinal Disord Tech 27(2):9397,2014

9. Loevner LA, Yousem DM: Overlooked metastatic lesions of the occipital condyle: A missed case treasure trove. Radiographics 17:1111-1121, 1997

10. Menezes AH: Craniocervical developmental anatomy and its implications. Childs Nerv Syst 24:1109-1122, 2008

11. Mingsheng T, Huimin W, Xin J, Ping $Y$, Hongyu W, Feng $Y$, Wu W: Screw fixation via diploic bone paralleling to occiput table: anatomical analysis of a new technique and report of 11 cases. Eur Spine J 16:2225-2231, 2007

12. Muthukumar N, Swaminathan R, Venkatesh G, Bhanumathy SP: A morphometric analysis of the foramen magnum region as it relates to the transcondylar approach. Acta Neurochir (Wien) 147:889-895, 2005

13. Ozer MA, Celik S, Govsa F, Ulusoy MO: Anatomical determination of a safe entry point for occipital condyle screw using three-dimensional landmarks. Eur Spine J 20:1510-1517, 2011

14. Sangvichien S: Accuracy of cranial and mandible morphological traits for sex determination in Thais. Siriraj Medical Journal 60:240-243, 2008

15. Takigawa T, Simon P, Espinoza Orias AA, Hong JT, Ito Y, Inoue N, An HS: Biomechanical comparison of occiput-C1-C2 fixation techniques: C0-C1 transarticular screw and direct occiput condyle screw. Spine (Phila Pa 1976) 37:E696-701, 2012

16. Uribe JS, Ramos E, Baaj A, Youssef AS, Vale FL: Occipital cervical stabilization using occipital condyles for cranial fixation: Technical case report. Neurosurgery 65:E1216-1217; discussion E1217, 2009 
17. Uribe JS, Ramos E, Vale F: Feasibility of occipital condyle screw placement for occipitocervical fixation: A cadaveric study and description of a novel technique. J Spinal Disord Tech 21:540546, 2008

18. Uribe JS, Ramos E, Youssef AS, Levine N, Turner AW, Johnson WM, Vale FL: Craniocervical fixation with occipital condyle screws: Biomechanical analysis of a novel technique. Spine (Phila Pa 1976) 35:931-938, 2010
19. Veroni A, Nikitovic D, Schillaci MA: Brief communication: Sexual dimorphism of the juvenile basicranium. Am J Phys Anthropol 141:147-151, 2010

20. Winegar CD, Lawrence JP, Friel BC, Fernandez C, Hong J, Maltenfort M, Anderson PA: A systematic review of occipital cervical fusion: Techniques and outcomes. J Neurosurg Spine 13:5-16, 2010

21. Yan WJ LJ, Jia LS: Application of modern fixation techniques in cervical-occipital surgery. Foreign medical sciences: Section of Orthopaedics 24: 335-337, 2003 